\title{
Cytological and immunohistochemical study of the limbal form of vernal keratoconjunctivitis by the replica technique
}

\author{
AHMED M ABU EL ASRAR,' KAREL GEBOES, ${ }^{2}$ LUC MISSOTTEN, ${ }^{3}$ \\ MOHAMED H EMARAH,', PRAHBAT C MAUDGAL ${ }^{3}$ AND VALEER DESMET \\ From the 'Department of Ophthalmology, Mansoura University Hospital, Egypt; and the ${ }^{3}$ Department of \\ Ophthalmology and ${ }^{2}$ Laboratory of Histochemistry and Cytochemistry, University Hospital St Rafaël, Leuven, \\ Belgium
}

SUMMARY The cellular composition of the inflammatory infiltrate present in 13 patients with the limbal form of vernal keratoconjunctivitis was examined in the conjunctival scrapings and the limbic replicas by means of Giemsa stain and immunohistochemistry. Conjunctival scrapings showed the presence of mast cells, lymphocytes, plasma cells, polymorphonuclear leucocytes, and very few basophils in all the specimens. Eosinophils were present in only four scrapings. The superficial epithelium of the limbic lesion and the adjacent cornea and conjunctiva was studied by the replica technique. The limbic lesion area showed the presence of necrotic epithelial cells mixed with inflammatory cells, including eosinophils, mast cells, lymphocytes, plasma cells, and polymorphonuclear leucocytes and very few basophils. Most of the inflammatory cells were HLA-DR ${ }^{+}$. Many $\mathrm{OKT}_{6}{ }^{+}$cells were present, indicating the presence of Langerhans cells. T-lymphocytes including a few helper/inducer cells and many suppressor/cytotoxic cells, were detected in the infiltrate. In addition many B-lymphocytes were observed. These findings suggest that other immune mechanisms in addition to type 1 reaction are involved in the pathogenesis of the disease.

Vernal keratoconjunctivitis is a chronic, seàsonally exacerbated bilateral external ocular inflammation. It is essentially a disease of childhood and youth, most frequently seen between the ages of 6 and 20 . The disease is more common in males until after puberty, when the incidence in both sexes tends to be more equal.'

There are three major forms of the disease: limbal, palpebral, and mixed. Coloured races are particularly prone to the limbal form of the disease,' and purely or predominantly limbal form of the disease appears to be found more frequently in black populations. ${ }^{23}$ Corneal findings are common and include punctate epithelial keratitis, epithelial macroerosion, plaque formation, subepithelial scarring, and pseudogerontoxon. ${ }^{4}$

Vernal keratoconjunctivitis is usually considered

Correspondence to Professor Dr L Missotten, Department of Ophthalmology, University Hospital St Rafaël, Kapucijnenvoer 7, B 3000 Leuven, Belgium. to be a type 1 hypersensitivity reaction mediated by IgE. This is suggested by the frequent presence of personal and family histories of atopy, ${ }^{5}$ by high $\operatorname{IgE}$ levels in serum and tears, ${ }^{6}$ by specific IgE antibodies to the pollen allergens in the tears, ${ }^{7}$ by elevated tear histamine levels, ${ }^{8}$ and by local and systemic eosinophilia. ${ }^{\prime}$

Locally produced pollen-specific IgG antibodies are detected in the tears of patients, suggesting that both IgE and IgG mediated immune mechanisms are involved in the pathogenesis of the disease. ${ }^{10}$ However, the mixed cellular infiltrate observed in the conjunctival tissues ${ }^{11-13}$ suggests that other immune mechanisms may play a part in the pathogenesis of the disease. Delayed-type hypersensitivity of the cutaneous basophil type may play a part in vernal keratoconjunctivitis owing to the occurrence of basophils in the conjunctival tissue. ${ }^{.1}$ This hypothesis is also supported by the predominance of helper/ inducer T-lymphocytes in the cellular infiltrate. ${ }^{14}$

The present study was undertaken to examine the 
cellular composition of the inflammatory infiltrate in the superficial epithelium of the limbic lesion and the adjacent cornea and conjunctiva in patients presenting with the limbal form of the disease. Monoclonal antibody staining techniques were employed to determine the involvement of $\mathrm{T}$ - and B-lymphocytes, Langerhans cells, and the expression of the major histocompatibility (MHC) class II antigens in material obtained by the replica technique.

\section{Subjects and methods}

\section{SUBJECTS}

Thirteen patients with the limbal form of vernal keratoconjunctivitis seen in the ophthalmic outpatient clinic of Mansoura University Hospital were included in the study. All the patients were examined by a slit-lamp. Cobalt blue filter and $2 \%$ sodium fluorescein solution were used to detect corneal ulcerations, and corneal and conjunctival changes were recorded.

The patients comprised eight males and five females. Their ages ranged from 4 years to 16 years, average 8.5 years. The symptoms given by the patients or their relatives were itching (13 patients), redness (eight patients), photophobia (six patients), lacrimation (three patients), and foreign body sensation (one patient).

The condition was bilateral in nine patients and unilateral in four. Circumcorneal disease was noted in all the patients, with encroachment on to the cornea in three patients (Fig. 1). The limbal lesion was greyish or pinkish and the bulbar conjunctiva near the cornea was injected. Trantas' dots were noted over the limbal lesion in two patients. Vernal keratopathy was noted in three patients. The first patient had an oval ulcer at the upper third of the

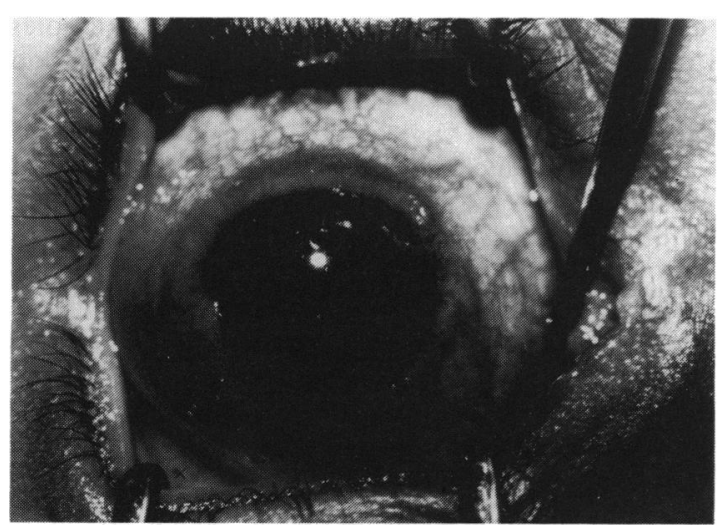

Fig. 1 Limbal form of vernal keratoconjunctivitis. Note the presence of cirumcorneal disease with encroachment on to the cornea. cornea with superficial stromal infiltration underneath, in addition to fine greyish punctate epithelial infiltrates distributed all over the cornea; the second patient had a whitish corneal plaque associated with epithelial opacification; the third patient showed punctate stains at the upper third of the cornea. Characteristic cobblestone papillae of the upper palpebral conjunctiva were noted only in the three patients with vernal keratopathy. The upper palpebral conjunctiva of another patient showed fine papillae. One patient with cobblestone papillae presented mechanical ptosis.

\section{CONJUNCTIVAL SCRAPINGS}

Conjunctival scrapings were taken from the upper palpebral conjunctiva under topical anaesthesia. The smears were air dried, fixed in absolute methyl alcohol for five minutes, and stained with Giemsa stain.

\section{LIMBIC REPLICAS}

Epithelium specimens from the limbic lesion and the surrounding cornea and conjunctiva were obtained by the replica technique. ${ }^{15}$ Replicas were obtained after drying the cornea and painting the lesion with a viscous solution of collodion in amyl acetate. After evaporation of the solvent the collodion membrane with the adhering superficial cells was peeled off. The replicas and the unstained flat mounts were examined by phase contrast and oblique illumination microscopy, and later subjected to immunohistochemical staining.

\section{IMMUNOHISTOCHEMICAL STUDY OF THE REPLICAS}

Ten replicas were stained by the following monoclonal antibodies: $\mathrm{OKT}_{4}$-Leu3a, $\mathrm{OKT}_{8}, \mathrm{~B}_{1}, \mathrm{OKT}_{6}$, HLA-DR. The OK series of monoclonal antibodies were purchased from Ortho Pharmaceutical Co, Raritan, NJ, USA; Leu3a and HLA-DR were obtained from Becton-Dickinson, Sunnyvale, CA, USA; $B_{1}$ was obtained from Coulter Electronic, Hialeah, FL, USA.

$\mathrm{OKT}_{4}$ and Leu3a define the helper/inducer T-cell subset $^{16}{ }^{17}$ and were applied simultaneously, ${ }^{18} \mathrm{OKT}_{8}$ defines the suppressor/cytotoxic T-cell subset, ${ }^{19}$ HLA-DR is directed against major histocompatibility (MHC) class II antigens. ${ }^{20} B_{1}$ reacts with all mature B-cells, ${ }^{21}$ and $\mathrm{OKT}_{6}$ defines cortical thymocytes, epidermal Langerhans cells, and interdigitating reticular cells. ${ }^{22} 23$

An indirect immunoperoxidase procedure was performed. ${ }^{24}$ Following incubation with peroxidaseconjugated rabbit antimouse Ig (Dakopatts a/s, Copenhagen, Denmark), the reaction product was developed with 3-amino-9-ethylcarbazole (Aldrich 


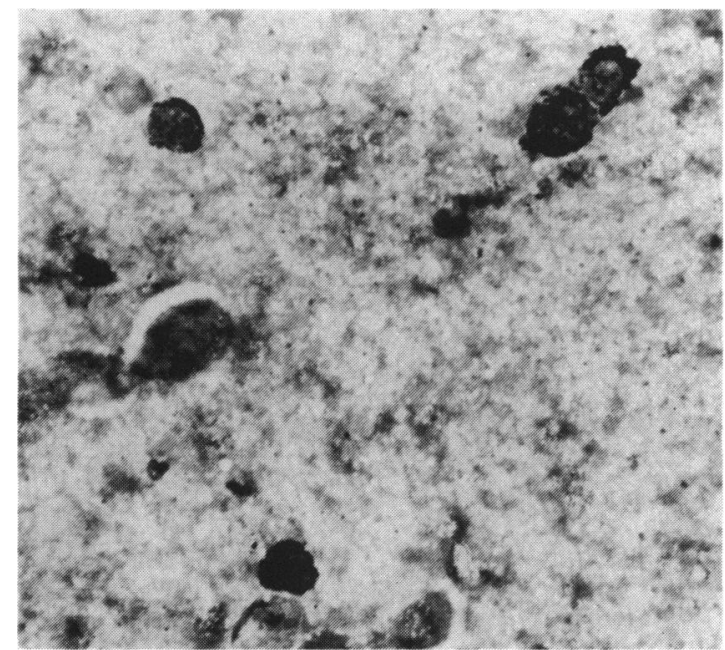

Fig. 2 Conjunctival scraping showing mast cells recognised by the presence of granules. Giemsa, $\times 470$.

Co Beerse, Belgium) and $\mathrm{H} 2 \mathrm{O} 2{ }^{25}$ The cells were briefly counterstained with Mayer's haemalum. Subsequently the cells were stained with Giemsa stain and examined by light microscopy.

\section{Results}

CONJUNCTIVAL SCRAPINGS

All the specimens contained sufficient number of cells. Many mast cells (Fig. 2), lymphocytes, plasma cells, and polymorphonuclear leucocytes were present in all the specimens. Occasionally very few basophils were seen. Eosinophils were present in only four specimens.

CYTOLOGICAL OBSERVATIONS OF THE REPLICAS The replicas obtained from all the patients contained the lesion area and the surrounding corneal and conjunctival epithelium. Phase contrast and oblique illumination microscopy of the replicas allowed us to study the shape and arrangement of the superficial epithelium. In the lesion area the epithelial cells were necrosed and were of irregular shape and arrangement. In the punctate lesions seen clinically localised patches formed of necrotic epithelial cells were observed (Fig. 3). Outside the lesion area most of the epithelial cells were intact. Only some were swollen, rounded, and occasionally fused.

Giemsa staining showed that the epithelial cells in the lesion area were necrotic. They had dark swollen nuclei with little or no cytoplasm. Dense collections

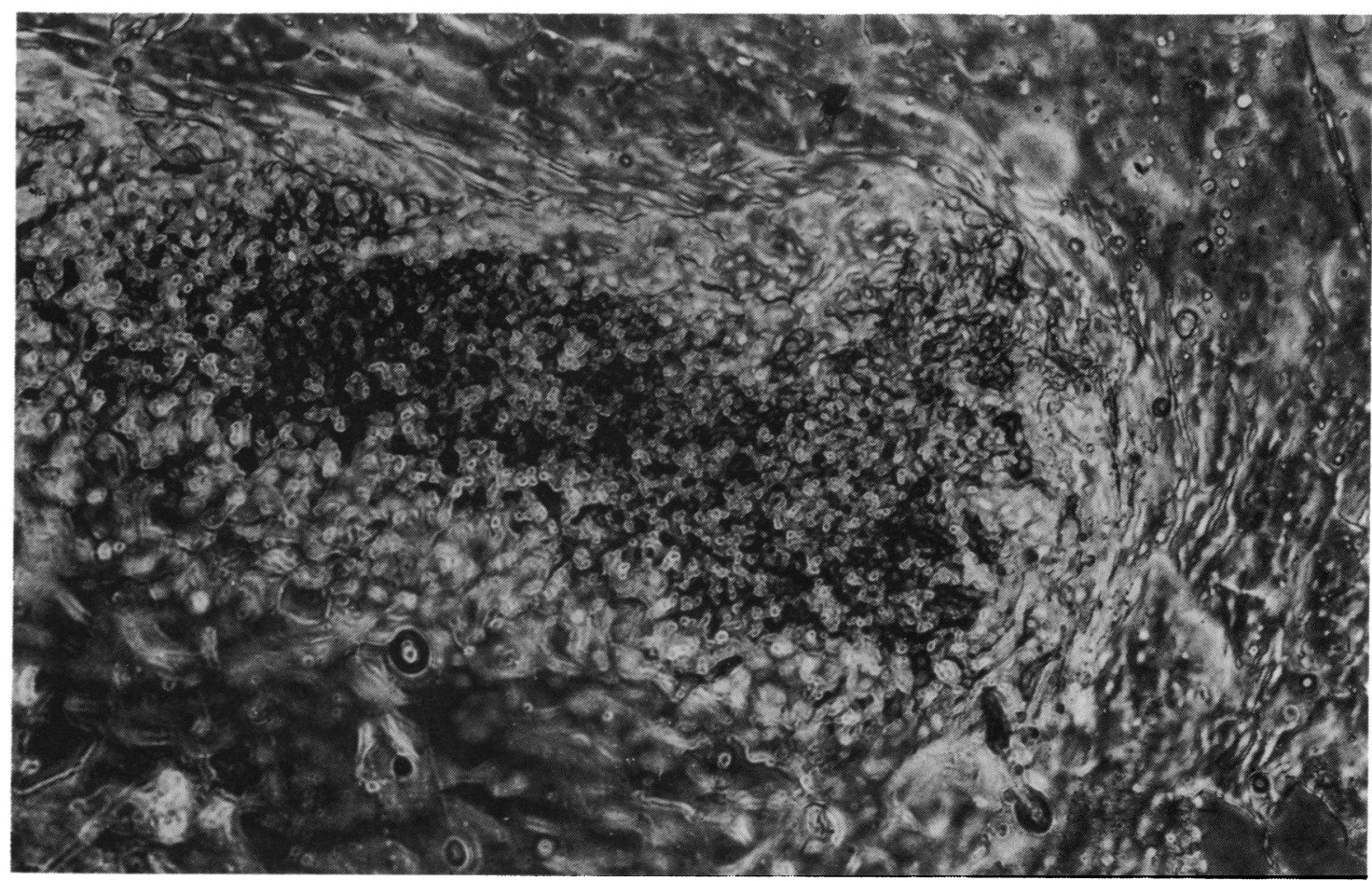

Fig. 3 Replica from a patient having vernal keratopathy. Note the presence of localised area of cell necrosis and degeneration representing a punctate clinical lesion. Phase contrast microscopy. $\times 175$. 
Fig. 4 Replicashowing necrotic epithelial cells mixed with inflammatory cells. Note the presence of many eosinophils (arrows). Giemsa, $\times 590$.

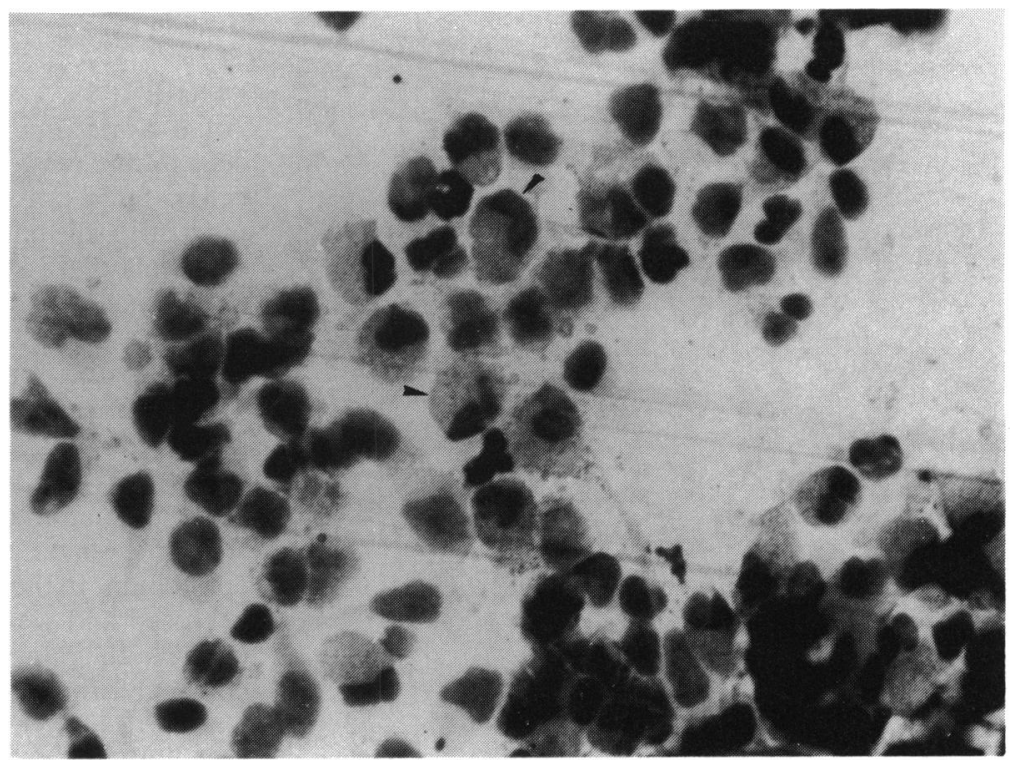

of inflammatory cells were present in the lesion area. In all cases the cellular infiltrate was composed of eosinophils which were either intact or fragmented with scattered eosinophilic granules, mast cells, lymphocytes, plasma cells, and polymorphonuclear leucocytes (Fig. 4). Basophils were occasionally seen. The surrounding epithelial cells showed granular cytoplasm. Some had swollen nuclei and others had small dark nuclei. Few inflammatory cells were seen scattered between these cells.

\section{IMMUNOHISTOCHEMICAL RESULTS}

Positive results were obtained in all the specimens examined. The epithelial cells in the limbic lesion area, as well as in the surrounding epithelium, were non-reactive for all the monoclonal antibodies used. The surface epithelium of the limbic lesion and the adjacent cornea and conjunctiva showed the presence of various types of inflammatory cells. These cells were present mainly in the area of the lesion, with few cells scattered in the surrounding epithelium. Most of.the inflammatory cells expressed the major histocompatibility (MHC) class II antigens. T-lymphocytes including few $\mathrm{OKT}_{4}-\mathrm{Leu3a}^{+}$ (helper/inducer) cells and many $\mathrm{OKT}_{8}{ }^{+}$(suppressor/ cytotoxic) cells were present. $\mathrm{B}_{1}{ }^{+}$cells were present in large numbers (Fig. 5). The presence of many $\mathrm{OKT}_{6}{ }^{+}$cells indicated the presence of accessory cells (Langerhans cells).

\section{Discussion}

The presence of eosinophils and free eosinophilic granules has been considered to be the most characteristic feature of the conjunctival scrapings in vernal disease. ${ }^{26}$ Kimura and Thygeson ${ }^{27}$ noted a characteristic fragmentation of the eosinophils in the conjunctival scrapings of patients with vernal conjunctivitis. We detected eosinophils in only four scrapings out of the 13 examined. Similar finding was noted by Abelson et al. ${ }^{28}$ who found eosinophils in the conjunctival scrapings of $63 \%$ of their patients with vernal conjunctivitis. They concluded that eosinophils present in deep and superficial conjunctival tissues as seen in biopsy specimens may not be recovered in scrapings; their absence from scrapings should not exclude the diagnosis of allergic ocular disease.

Numerous mast cells were present in the conjunctival scrapings of all the patients. On the other hand very few basophils were occasionally seen, indicating that mast cells are predominant in the conjunctival scrapings of our patients. In addition the scrapings showed lymphocytes, plasma cells, and polymorphonuclear leucocytes.

Epithelial invasion by mast cells, eosinophils, and basophils has been reported in vernal conjunctivitis. ${ }^{12}$ Polymorphs ${ }^{13}$ and lymphocytes" were also noted.

The replica technique allowed us to study the superficial epithelium and the distribution of inflammatory cells in the limbic lesion and the adjacent corneal and conjunctival epithelium. In the limbic lesion area the epithelial cells were necrosed and lost their normal hexagonal shape and arrangement. They were mixed with dense collections of inflammatory cells. Outside the lesion area the epithelial cells 


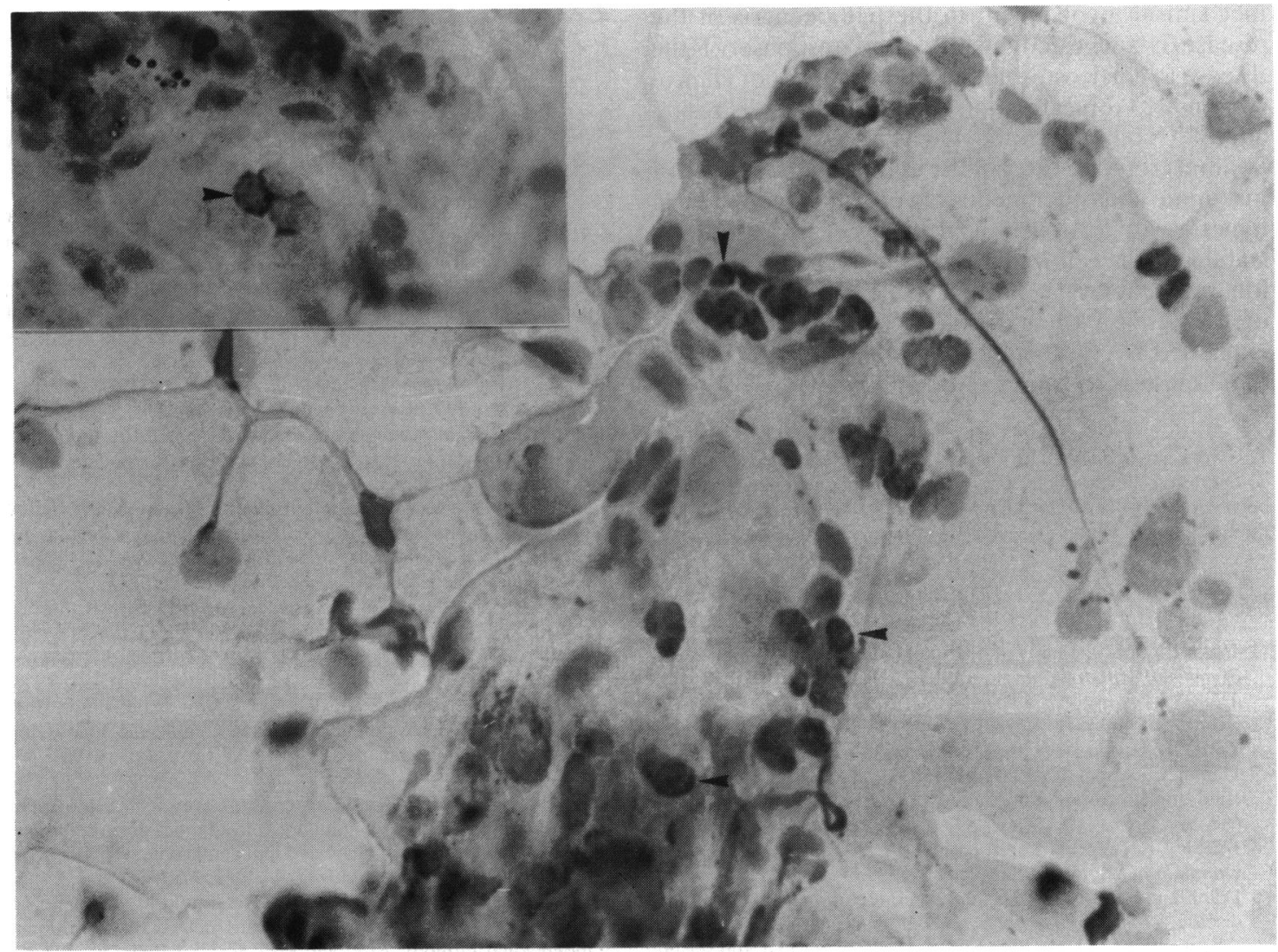

Fig. 5 Limbic replica showing the presence of $B_{1}{ }^{+} B$-lymphocytes (arrows). As shown in the insertion the positive reaction is a membranous staining. Immunoperoxidase, $\times 778$.

were more or less of normal shape and arrangement, but some of them were swollen, rounded, and occasionally fused. Few inflammatory cells were seen scattered outside the lesion area. The inflammatory infiltrate in the limbic lesion was composed of many eosinophils which were either intact or fragmented with the release of their granules, mast cells, lymphocytes, plasma cells, and polymorphonuclear leucocytes. As we observed in the conjunctival scrapings, basophils were very few and mast cells were predominant. Eosinophils were noted in all the limbic specimens obtained by the replica technique in spite of their presence in only four conjunctival scrapings. This indicates that examining the limbic lesion by the replica technique was more valuable than examining conjunctival scrapings in investigating this disease.

Immunohistochemical staining showed that most of the inflammatory cells present in the lesion area expressed major histocompatibility (MHC) class II antigens, indicating that they are immunologically active. We noted that many B-lymphocytes were present in the cellular infiltrate. This observation can explain the findings of other authors who noted elevated levels of $\operatorname{IgE}$ in the tears of patients with vernal keratoconjunctivitis. T-lymphocytes including

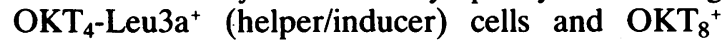
(suppressor/cytotoxic) cells were also present. However, $\mathrm{OKT}_{4}-\mathrm{Leu}_{3} \mathrm{a}^{+}$cells were present in small numbers. Many $\mathrm{OKT}_{6}{ }^{+}$cells were detected in the lesion area, indicating the presence of Langerhans cells. Langerhans cells function as antigen presenting and activating cells for T-lymphocytes. ${ }^{29}$

Our data indicate that B-lymphocytes, Tlymphocytes, and Langerhans cells are involved, suggesting that other immune mechanisms in addition to type 1 reaction are participating in the pathogenesis of the disease and points to a complex immunopathogenesis. From our work we can conclude that humoral immunity and cell mediated immunity are involved. Other authors" suggested that delayed-type hypersensitivity of the cutaneous basophil type may be involved owing to the presence of basophils in conjunction with other pathological changes. In addition a non-IgE-mediated immune 
mechanism involvement in the pathogenesis of the disease is suggested by the good response of the disease to corticosteroid therapy, by the poor clinical response to topical antihistamines, and by its resistance to sodium cromoglycate in some patients. Sodium cromoglycate acts by inhibiting the release of histamine and other mediators of immediate (type 1) hypersensitivity reaction in mast cells, possibly by stabilising the cell wall membrane to changes in $\mathrm{Ca}^{++}$ ion permeability. ${ }^{30}$ This variable clinical response of the disease to these lines of treatment can be explained by the complex immunopathogenesis of the disease as shown by our data.

This work was supported by the programme of scientific and clinical co-operation in the field of ophthalmic medicine and surgery between the University of Mansoura, Arab Republic of Egypt, and the Catholic University, Leuven, Belgium.

\section{References}

1 Duke-Elder S. Diseases of the outer eye. In: Duke-Elder S, ed. System of ophthalmology. London: Kimpton, 1965; 8 (1): 475-93.

2 Sandford-Smith JH. Vernal eye disease in Northern Nigeria. Trop Geogr Med 1979; 31: 321-8.

3 Dahan E, Appel R. Vernal keratoconjunctivitis in the black child and its response to therapy. Br J Ophthalmol 1983; 67: 688-92.

4 Buckley RJ. Vernal keratopathy and its management. Trans Ophthalmol Soc UK 1981; 101: 234-8.

5 Frankland AW, Easty DL. Vernal keratoconjunctivitis an atopic disease. Trans Ophthalmol Soc UK 1971; 91: 479-82.

6 Allansmith MR, Hahn GS, Simon MA. Tissue, tear and serum IgE concentrations in vernal conjunctivitis. Am J Ophthalmol 1976; 81: 506-11.

7 Ballow M, Mendelson L. Specific immunoglobulin E antibodies in tear secretions of patients with vernal conjunctivitis. $J$ Allergy Clin Immunol 1980; 66: 112-8.

8 Abelson MB, Soter NA, Simon MA, Dohlman J, Allansmith MR. Histamine in human tears. Am J Ophthalmol 1977; 83: 417-21.

9 Alimuddin M. Vernal conjunctivitis. Br J Ophthalmol 1955; 39: 160-3.

10 Ballow M, Donshik PC, Mendelson L, Rapacz P, Sparks K. IgG specific antibodies to rye grass and ragweed pollen antigens in the tear secretions of patients with vernal conjunctivitis. Am J Ophthalmol 1983; 95: 161-8.

11 Collin HB, Allansmith MR. Basophils in vernal conjunctivitis in humans: an electron microscopic study. Invest Ophthalmol Vis Sci 1977; 16: 858-64.

12 Allansmith MR, Baird KS, Greiner JV. Vernal conjunctivitis and contact lens-associated giant papillary conjunctivitis compared and contrasted. Am J Ophthalmol 1979; 87: 544-55.

13 Easty DL, Birkenshaw M, Merrett T, Merrett J, Entwhistle C,
Amer B. Immunological investigations in vernal eye disease. Trans Ophthalmol Soc UK 1980; 100: 98-107.

14 Bhan AK, Fujikawa LS, Foster CS. T-cell subsets and Langerhans cells in normal and diseased conjunctiva. Am J Ophthalmol 1982; 94: 205-12.

15 Missotten L, Maudgal PC. The replica technique used to study superficial corneal epithelium in vivo. Am J Ophthalmol 1977; 84: 104-11.

16 Reinherz EL, Kung PC, Goldstein G, Schlossman SF. Further characterization of the human inducer $T$-cell subset defined by a monoclonal antibody. J Immunol 1979; 123: 2894-6.

17 Ledbetter JA, Evans RL, Lipinski M, Cunningham-Rundles C, Good RA, Herzenberg LA. Evolutionary conservation of surfact molecules that distinguish T-lymphocyte helper/inducer and cytotoxic/suppressor subpopulations in mouse and man. J Exp Med 1981; 153: 310-23.

18 Van den Oord JJ, de Wolf-Peeters C, Vanstapel MJ, Desmet VJ. Improved visualization of helper/inducer T-cells by the simultaneous application of two, non-crossblocking monoclonal antibodies. Stain Technol 1985; 60: 45-9.

19 Reinherz EL, Kung PC, Goldstein G, Schlossman SF. A monoclonal antibody reactive with the human cytotoxic/ suppressor T-cell subset previously defined by a heteroantiserum termed TH2.J Immunol 1980; 124: 1301-7.

20 Van der Valk P, van der Loo EM, Jansen J, Daha MR, Meijer CJLM. Analysis of lymphoid and dendritic cells in human lymph node, tonsil and spleen. Virchows Arch (Cell Pathol) 1984; 45: 169-85.

21 Nadler LM, Stashenko P, Ritz J, Hardy R, Pesando JM, Schlossmann SF. A unique cell surface molecule identifying lymphoid malignancies of B-cell origin. J Clin Invest 1981; 67: 134-40.

22 Reinherz EL, Kung PC, Goldstein G, Levey RH, Schlossman SF. Discrete stages of human intrathymic differentiation: analysis of normal thymocyte and leukaemic lymphoblasts of $T$ cell lineage. Proc Natl Acad Sci USA 1980; 77: 1588-92.

23 Fithian E, Kung PC, Goldstein G, Rubenfeld M, Fenoglio C, Edelson R. Reactivity of Langerhans cells with hybridoma monoclonal antibody. Proc Natl Acad Sci USA 1981; 78: 2541-4.

24 Mason DY, Naiem M, Abdulaziz Z, Nash JRG, Gatter KC, Stein $\mathrm{H}$. Immunohistochemical labelling of cryostat sections with monoclonal antibody. In: McMichael AJ, Fabre JW, eds. Monoclonal antibodies in clinical medicine. London: Academic Press, 1982: 632-5.

25 Graham RC, Lundholm, U, Karnovsky MJ. Cytochemical demonstration of peroxidase activity with 3-amino-9ethylcarbazole. J Histochem Cytochem 1965; 13: 150-2.

26 Grayson M. Diseases of the cornea. St Louis: Mosby, 1979.

27 Kimura SJ, Thygeson P. The cytology of external ocular disease. Am J Ophthalmol 1955; 39: 137-45.

28 Abelson MB, Madiwale N, Weston JH. Conjunctival eosinophils in allergic ocular disease. Arch Ophthalmol 1983; 101: 555-6.

29 Morris HHB, Gatter KC, Stein H, Mason DY. Langerhans cells in human cervical epithelium: an immunohistological study. $B r J$ Obstet Gynaecol 1983; 90: 400-11.

30 Foreman JC, Garland LG. Cromoglycate and other antiallergic drugs: a possible mechanism of action. Br Med J 1976; i: 820-1.

Accepted for publication 31 October 1986. 